\title{
A four-year nationwide molecular epidemiological study in Estonia: risk factors for tuberculosis transmission
}

\author{
K. Toit, ${ }^{1,2}$ A. Altraja, ${ }^{2,3}$ C. D. Acosta, ${ }^{4}$ P. Viiklepp, ${ }^{5}$ K. Kremer, ${ }^{4,6}$ T. Kummik, ${ }^{1}$ M. Danilovitš, ${ }^{3}$ \\ R. Van den Bergh,7 A. D. Harries, ${ }^{8,9}$ P. Supply10,11,12,13
}

http://dx.doi.org/10.5588/pha.14.0045

Setting: Estonia has a high proportion of multidrug-resistant tuberculosis (MDR-TB). It is important to link molecular and epidemiological data to understand TB transmission patterns.

Objective: To use 24-locus variable numbers of tandem repeat (VNTR) typing and national TB registry data in Estonia from 2009 to 2012 to identify the distribution of drug resistance patterns, Mycobacterium tuberculosis isolate clustering as an index for recent transmission, socio-demographic and clinical characteristics associated with recent transmission, and the distribution of transmission between index and secondary cases.

Design: A retrospective nationwide cross-sectional study. Results: Of 912 cases with isolate and patient information, $39.1 \%$ of isolates were from the Beijing lineage. Cluster analysis identified 87 clusters encompassing $69.1 \%$ of isolates. The largest cluster comprised 178 isolates from the Beijing lineage, of which $92.1 \%$ were MDR- or extensively drug-resistant TB (XDR-TB). Factors associated with recent transmission were polyresistant TB, MDR- and XDR-TB, human immunodeficiency virus positivity, Russian ethnicity, non-permanent living situation, alcohol abuse and detention. XDR-TB cases had the highest risk of recent transmission. The majority of transmission cases involved individuals aged 30-39 years.

Conclusion: Recent TB transmission in Estonia is high and is particularly associated with MDR- and XDR-TB and the Beijing lineage.

$\mathrm{T}$ he smallest Baltic country, Estonia (population 1.3 million) suffers from a relatively high rate of tuberculosis (TB) in the European context, and is among the world's 27 high multidrug-resistant TB (MDR-TB) burden countries. ${ }^{1}$ The TB incidence rate declined from 36.6 per 100000 population in 2007 to $21.6 / 100000$ in 2012 . However, a quarter $(25.5 \%)$ of the 234 new cases reported in 2012 were MDR-TB (defined as resistance to at least isoniazid and rifampicin [RMP]), of which $6.6 \%$ were extensively drug-resistant TB (XDR-TB, defined as MDR-TB plus resistance to a fluoroquinolone and one of the three injectables). ${ }^{2}$ Recent studies in Estonia showed that human immunodeficiency virus (HIV) infection, homelessness and alcohol abuse significantly increase the risk for XDR-TB. ${ }^{3}$ However, the extent to which these determinants contribute to TB transmission is unknown.
Molecular epidemiology has contributed significantly to our understanding of TB transmission. Studies using this approach have helped to determine what proportion of active TB is due to reinfection or reactivation and to identify risk factors for TB transmission within communities. ${ }^{4}$ For such studies, the most commonly used methods for Mycobacterium tuberculosis DNA fingerprinting are insertion sequence (IS) 6110 restriction fragment length polymorphism $(\text { RFLP })^{5}$ and 24-locus variable numbers of tandem repeat (VNTR) typing, ${ }^{6}$ which were internationally standardised in 1993 and 2006, respectively. VNTR typing has various advantages over RFLP typing, including its ease of use, short turnaround time and digital output format. In addition, several population-based studies have shown that the predictive value of VNTR typing to study TB transmission is similar to that of RFLP typing in different Western European settings.7,8 The current gold standard in molecular epidemiology of TB is therefore VNTR typing, which produces a numeric pattern enabling the identification of $M$. tuberculosis strains. ${ }^{9}$ It is assumed that patients infected with $M$. tuberculosis isolates with identical DNA fingerprints are 1) infected with the same M. tuberculosis strain and 2) have infected each other, have a common source of infection or were independently infected by a highly prevalent strain circulating in the community. Conversely, it is assumed that patients who are infected with a strain with a unique DNA fingerprint in a population are either suffering from a reactivation of a previous infection or from infection with a strain that was newly introduced into the population by the patient. Investigators have thus used molecular clustering, defined as matching of identical DNA fingerprints, as an index of TB transmission.

The first study to use RFLP DNA fingerprinting results conducted in Estonia showed high clustering rates among MDR-TB isolates, and suggested an association between the Beijing genotype of $M$. tuberculosis and drug resistance. ${ }^{10} \mathrm{~A}$ later study that compared DNA fingerprints from MDR-TB cases reported in Europe during the years 2003-2007 showed that these Beijing strains persisted in Estonia and were part of a large cluster of MDR-TB strains (designated as cluster E0051) detected in 12 different countries. ${ }^{11}$ In 2009, Estonia started using VNTR typing within the framework of the TB PAN-NET project; ${ }^{12}$ one of the project's aims was to study TB transmission in European countries.
AFFILIATIONS

1 United Laboratories, Tartu University Hospital, Tartu, Estonia

2 Department of Pulmonary Medicine, University of Tartu, Tartu, Estonia

3 Lung Clinic, Tartu University Hospital, Tartu, Estonia

4 Tuberculosis and $\mathrm{M}$ / XDR-TB Programme, Division of

Communicable Diseases, Health Security \& Environment, World Health Organization Regional Office for Europe, Copenhagen, Denmark

5 National Institute for Health Development, Tallinn, Estonia

6 Centre for Infectious Diseases Control, National Institute of Public Health and the Environment, Bilthoven The Netherlands

7 Medical Department, Brussels Operational Center, Médecins Sans Frontières MSF-Luxembourg, Luxembourg

8 International Union Against Tuberculosis and Lung Disease, Paris, France

9 London School of Hygiene \& Tropical Medicine, London, UK

10 Institut National de la Santé et de la Recherche Médicale 1019, Lille, France

11 Unités Mixtes de Recherche 8204, Centre national de la Recherche scientifique, Lille, France

12 Center for Infection and Immunity of Lille, Institut Pasteur de Lille, Lille, France

13 University Nord de France, Lille, France

CORRESPONDENCE Kadri Toit, Department of Mycobacteriology United Laboratories Tartu University Hospital

Puusepa 1a

50406 Tartu, Estonia

Tel: (+372) 7428262 e-mail: Kadri.Toit@kliinikum.ee

KEY WORDS

Beijing lineage; clustering; MDR-TB; SORT IT;

operational research

Received 4 May 2014 Accepted 27 July 2014

PHA2014;4(3):S34-S40 (C) 2014 The Union 
The current study used VNTR patterns generated within the framework of the TB PAN-NET project to construct a database that was linked to the Estonian National TB Registry (NTR) to assist TB control activities. In particular, we performed cluster analysis of the DNA fingerprints with the aim of identifying risk groups that can be targeted by the National TB Programme (NTP) to improve prevention of TB transmission.

\section{METHODS}

\section{Study design}

This was a retrospective nationwide cross-sectional study.

\section{Setting}

Estonia is a small European country neighbouring Latvia, Finland and the Russian Federation, with a population of approximately 1.3 million. About $30 \%$ of the population lives in the capital, Tallinn. ${ }^{13}$ About $70 \%$ of the population are of Estonian ethnicity, 25\% are Russians and the remaining 5\% include various ethnic groups from the former Soviet Union and Eastern Europe.

Since 1998, the institutions managing anti-tuberculosis treatment in Estonia have followed NTP guidelines, which are in line with the World Health Organization TB guidelines. ${ }^{14}$ TB case finding is mainly passive, and diagnosis is established through sputum smear microscopy, culture and chest radiography for pulmonary TB and other investigations for extra-pulmonary TB. All TB patients are registered with a unique registration number at the NTR, given standardised, mainly hospital-based, treatment and monitored for treatment outcomes according to national and international recommendations. ${ }^{15}$ All TB services, anti-tuberculosis treatment, and, if necessary, opioid substitute therapy (OST), are free in the country.

\section{Patient sample}

All patients with a positive culture and both DST and VNTR typing results available for that culture during the period January 2009-December 2012 were included in the study.

\section{Data sources and collection}

There are two TB culture laboratories in Estonia: one in Tallinn and the TB reference laboratory in Tartu. All specimens for TB diagnosis in the country are sent to one of these two laboratories. All positive cultures are subjected to first-line drug susceptibility testing (DST) ${ }^{16}$ and, in case of resistance to first-line drugs, DST for second-line drugs is performed. ${ }^{17}$ The TB reference laboratory in Tartu archives all TB isolates that have DST results available and is responsible for DNA genotyping. Within the framework of the TB PAN-NET project, genotyping of the isolate DNA was performed by the Institute Pasteur de Lille (Lille, France) using the standard VNTR typing method ${ }^{6}$ and mycobacterial interspersed repetitive units (MIRU) VNTR typing kits from Genoscreen (Lille, France). The typing was rigorously quality controlled by the inclusion of positive (M. bovis bacille Calmette-Guérin DNA) and negative con- trols and internal procedures. When evaluated in independent proficiency studies of VNTR typing, this laboratory systematically obtained $100 \%$ intra- and inter-laboratory reproducibility scores. ${ }^{9,18}$ A database with VNTR patterns of all culture-positive cases is kept at the Tartu Reference Laboratory.

All patient characteristics and demographic data were collected from the Estonian NTR. VNTR patterns were collected from the TB reference laboratory and DST results were collected from the NTR. Data from different sources were matched using unique patient identifiers, names and birth dates. Data from the linked databases were collected into an EpiData database (EpiData Association, Odense, Denmark).

\section{Data analysis and statistics}

Cluster analysis of VNTR patterns and lineage assignment was performed using the MIRU-VNTRplus database. ${ }^{19}$ Cluster analysis was conducted using the unweighted pair group method with arithmetic mean (UPGMA) and the categorical coefficient. ${ }^{20}$ A cluster was defined as at least two isolates with 100\% identical VNTR typing patterns. An index case was defined as chronologically the first case in a cluster. Clustering of VNTR patterns was used as a measure of TB transmission. Lineages were assigned using the similarity search provided in the MIRU-VNTRplus database using a distance maximal genotypic distance of 0.17 and treebased identification using the neighbour-joining algorithm. ${ }^{21,22}$

The number and sizes of clusters and the genetic background of these clusters were tabulated. Associations between different patient characteristics and isolate clustering were assessed, and risk ratios (RRs) and corresponding 95\% confidence intervals (CIs) were calculated. Differences at the 5\% level $(P<0.05)$, calculated using Pearson's $\chi^{2}$ test, were considered statistically significant. All data were analysed using EpiData version 2.2.2.182 (EpiData Association).

\section{Ethics approval}

Ethics approval was granted both by the Research Ethics Committee of the University of Tartu, Tartu, Estonia, and by the International Union Against Tuberculosis and Lung Disease Ethics Advisory Group, Paris, France. Permission for collecting, handling and analysing patient data was obtained from the Estonian Data Protection Inspectorate and the Ministry of Social Affairs, Talinn, Estonia.

\section{RESULTS}

Of the $1371 \mathrm{~TB}$ cases identified in Estonia during the 4-year study period, 1286 (93.8\%) had pulmonary TB, $1080(78.8 \%)$ were new cases with no previous anti-tuberculosis treatment and 1066 (77.8\% of total) were culture-positive TB cases. Of these, 917 (86.0\%) had VNTR patterns available for their isolates in the National TB Reference Laboratory database. For 912 cases, including nine patients registered twice as a result of recurrent $\mathrm{TB}$, a link between the patient and isolate information could be established.

Lineages could be assigned to $86.2 \%$ of the 912 iso-
ACKNOWLEDGEMENTS This research was conducted through the Structured Operational Research and Training Initiative (SORT IT), a global partnership led by the Special Programme for Research and Training in Tropical Diseases at the World Health Organization (WHO-TDR). The specific SORT IT programme which resulted in this publication was jointly developed and implemented by WHO-TDR, the WHO Regional Office for Europe (Copenhagen, Denmark), the Operational Research Unit (LUXOR), Brussels Operational Center, Médecins Sans Frontières (MSF Luxembourg), the Centre for Operational Research, International Union Against Tuberculosis and Lung Disease (The Union; Paris, France), The Union South-East Asia Regional Office, New Delhi, India.

We are grateful for the support of the WHO Country Office in Talinn, Estonia, and the Estonia National Institute for Health and Development (Talinn, Estonia) in hosting the training workshops. We also appreciate the active

involvement of the WHO Country Office and the Ministry of Health (Talinn, Estonia) in the selection of candidates for training in operational research and dentification of reserch dentification of research projects

The research leading to these results received funding from the European Community's Seventh Framework

Programme (FP7/2007-2013) under grant agreement FP7-223681. The SORT IT programme was funded by the United States Agency for International Development

(Washington DC, USA) through a grant managed by WHO-TDR. Additional suppor was provided by the WHO Regional Office for Europe, the Department for International Development (London, UK) and MSF. The funders had no role in study design, data collection and analysis, decision to publish, or preparation of the manuscript.

Conflict of interest: PS is a consultant for Genoscreen. The other authors declare no conflict of interest.

In accordance with WHO's open-access publication policy for all work funded by WHO or authored/ co-authored by WHO staff members, the $\mathrm{WHO}$ retains the copyright of this publication through a Creative Commons Attribution IGO license (http://creativecommons.org/ licenses/by/3.0/igo/ legalcode), which permits unrestricted use, distribution, and reproduction in any medium provided the origina work is properly cited. The authors alone are responsible for the content of this paper which may not necessarily represent the policies, decisions or views of the WHO. 
TABLE 1 Anti-tuberculosis drug resistance patterns and the distribution of different lineages of patient isolates in culture-positive TB cases, Estonia, 2009-2012

\begin{tabular}{|c|c|c|c|c|c|c|c|}
\hline \multirow[b]{2}{*}{ Resistance pattern } & \multirow[b]{2}{*}{$\begin{array}{c}\text { Total } \\
n\end{array}$} & \multicolumn{6}{|c|}{ Proportion of $M$. tuberculosis lineages } \\
\hline & & $\begin{array}{c}\text { Beijing } \\
n(\%)\end{array}$ & $\begin{array}{c}\text { Haarlem } \\
n(\%)\end{array}$ & $\begin{array}{l}\text { LAM } \\
n(\%)\end{array}$ & $\begin{array}{l}\text { Ural } \\
n(\%)\end{array}$ & $\begin{array}{c}\text { Unknown } \\
n(\%)\end{array}$ & $\begin{array}{l}\text { Other } \\
n(\%)\end{array}$ \\
\hline Susceptible & 602 & $101(16.8)$ & $168(27.9)$ & $131(21.8)$ & $72(12.0)$ & $122(20.3)$ & $8(1.4)$ \\
\hline INH-monoresistant & 15 & $2(13.3)$ & $4(26.7)$ & $6(40.0)$ & - & $3(20.0)$ & - \\
\hline RMP-monoresistant & 7 & $1(14.3)$ & - & $5(71.4)$ & - & $1(14.3)$ & - \\
\hline Polyresistant* & 47 & $30(63.8)$ & $2(4.3)$ & $7(14.9)$ & $8(17.0)$ & - & - \\
\hline MDR-TB & 134 & $126(94.0)$ & $2(1.5)$ & $3(2.2)$ & $3(2.2)$ & - & - \\
\hline $\mathrm{MDR}-\mathrm{TB}+\mathrm{AG} / \mathrm{CP}$ & 54 & $45(83.3)$ & - & $9(16.7)$ & - & - & - \\
\hline MDR-TB+FQ & 26 & $26(100.0)$ & - & - & - & - & - \\
\hline XDR-TB & 27 & $26(96.3)$ & - & $1(3.7)$ & - & - & - \\
\hline Total & 912 & $357(39.2)$ & $176(19.3)$ & $162(17.8)$ & $83(9.1)$ & $126(13.8)$ & $8(0.8)$ \\
\hline
\end{tabular}

${ }^{*}$ Resistant to at least two of the first-line drugs, but not MDR-TB.

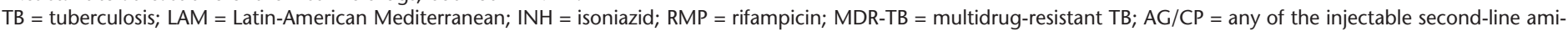
noglycosides or capreomycin; $\mathrm{FQ}=$ fluoroquinolone; $\mathrm{XDR}-\mathrm{TB}=$ extensively drug-resistant TB.

lates (cases). The distribution of lineages according to DST pattern is shown in Table 1 . The largest overall proportion of isolates $(n=$ $357,39.2 \%$ ) was from the Beijing lineage. Drug-susceptible isolates were evenly distributed across the four main lineages (Beijing, Haarlem, Latin-American-Mediterranean [LAM] and Ural). In contrast, most MDR- and XDR-TB isolates were from the Beijing lineage (94.0\% and 96.3\%, respectively). In addition, five of seven RMP-monoresistant isolates (71.4\%) were from the LAM lineage.

In total, there were 87 clusters comprising 630 (69.1\%) isolates (Figure 1). Ten clusters had more than 10 isolates, with four clusters having over 20 isolates. The largest cluster, containing 178 isolates, consisted of the Beijing lineage strain MtbC 15-9 type $100-32$, according to the standard VNTR typing nomenclature; 21,23 164 (92.1\%) of these were MDR- or XDR-TB. In contrast, the second largest cluster comprised 32 isolates from the LAM lineage, of which 30 (94.0\%) were drug-susceptible. The third largest cluster comprised 30 isolates from another Beijing lineage strain (MtbC 15-9 type 94-32), of which 9 (30.0\%) were MDR- or XDR-TB.

Socio-demographic factors associated with an increased risk of clustering were Russian ethnicity, non-permanent living conditions, alcohol abuse and history of incarceration, while factors associated with a reduced risk of clustering were older age, being born in Ukraine, being of Belarusian ethnicity, living in Tartu and having a lower education level (Table 2). The clinical factors associated with an increased risk of clustering were polyresistant, MDR- and XDR-TB, and being HIV-positive (Table 3). XDR-TB cases had the highest risk of clustering (RR 1.63, $P<0.001$ ). Extra-pulmonary $\mathrm{TB}$ was associated with a reduced risk of clustering.

The distribution of transmission between index cases and secondary cases in relation to different age groups is shown in Figure 2. Transmission occurred most frequently from the 30-39 year age group. The majority of secondary cases were distributed among those aged 30-59 years.

\section{DISCUSSION}

This is the first molecular epidemiological study in Estonia using the VNTR methodology to examine associations between patients, their characteristics, M. tuberculosis strains and clustering to determine where recent TB transmission has occurred. There were several important findings.
First, the most frequent isolates were from the Beijing lineage, which were particularly associated with drug-resistant TB. Over $90 \%$ of patients with MDR-TB, MDR-TB with additional resistance to second-line drugs and XDR-TB, were infected with isolates from the Beijing lineage. The association between severe drug resistance and the Beijing lineage is well established worldwide; 24,25 in Estonia, this association was already demonstrated in 2001 with isolates that originated from 1994.10 Our data thus demonstrate a continuous, longitudinal persistence of this association in Estonia. Another interesting but unexpected finding was that the small number of isolates with RMP monoresistance largely came from the LAM lineage (5/7). Of note, $4 / 5$ isolates were distributed into two clusters and one had a unique VNTR pattern. This indicates both recent transmission of RMP-monoresistant TB and independent acquisition of this resistance pattern. Nevertheless, patients with RMP monoresistance require MDR-TB treatment rather than first-line anti-tuberculosis treatment, ${ }^{26}$ indicating that this particular pattern of drug resistance needs to be carefully monitored in the future.

Second, almost $70 \%$ of the isolates were clustered, indicating a high degree of recent TB transmission in the community. This is significantly higher than shown previously for Estonia from cases examined 20 years ago (49\%). ${ }^{10}$ Importantly, there were several clusters suggesting transmission chains involving large groups of $\geqslant 10$ persons. The largest cluster, of 178 isolates, consisted of the Beijing lineage strain, which was recently reported to be the ma-

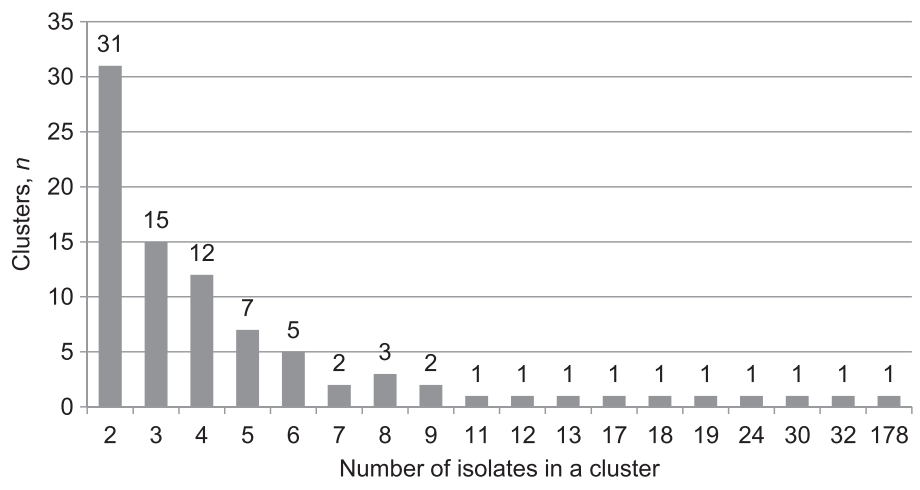

FIGURE 1 Number and sizes of clusters present in patients with culture-positive tuberculosis, Estonia, 2009-2012. 
TABLE 2 Socio-demographic characteristics of patients with culture-positive tuberculosis in relation to clusters, Estonia, 2009-2012

\begin{tabular}{|c|c|c|c|c|}
\hline Risk factor & $\begin{array}{c}\text { Total } \\
n\end{array}$ & $\begin{array}{c}\text { Clustered } \\
n(\%)\end{array}$ & $\mathrm{RR}(95 \% \mathrm{Cl})$ & $P$ value \\
\hline \multicolumn{5}{|l|}{ Sex } \\
\hline Male & 638 & $449(70.4)$ & $1.07(0.97-1.18)$ & 0.20 \\
\hline Female & 274 & $181(66.0)$ & 1.0 & \\
\hline \multicolumn{5}{|l|}{ Age, years } \\
\hline$<20$ & 16 & $12(75.0)$ & $1.01(0.75-1.35)$ & 1.0 \\
\hline $20-29$ & 110 & $91(82.7)$ & $1.11(0.99-1.25)$ & 0.10 \\
\hline $30-39$ & 178 & $144(80.9)$ & $1.09(0.97-1.21)$ & 0.14 \\
\hline $40-49$ & 200 & $149(74.5)$ & 1.0 & \\
\hline $50-59$ & 198 & $142(71.7)$ & $0.96(0.85-1.08)$ & 0.53 \\
\hline $60-69$ & 101 & $59(58.4)$ & $0.78(0.65-0.94)$ & $<0.01$ \\
\hline$\geqslant 70$ & 109 & $33(30.3)$ & $0.41(0.30-0.55)$ & $<0.001$ \\
\hline \multicolumn{5}{|l|}{ Country of birth } \\
\hline Estonia & 772 & $550(71.2)$ & 1.0 & \\
\hline Russia & 96 & $62(64.6)$ & $0.91(0.78-1.06)$ & 0.18 \\
\hline Ukraine & 15 & $4(26.7)$ & $0.37(0.16-0.87)$ & $<0.001$ \\
\hline Belarus & 11 & $6(54.5)$ & $0.77(0.45-1.32)$ & 0.23 \\
\hline \multicolumn{5}{|l|}{ Ethnicity of the patient } \\
\hline Estonian & 515 & $348(67.6)$ & 1.0 & \\
\hline Russian & 320 & $242(75.6)$ & $1.12(1.03-1.22)$ & 0.01 \\
\hline Belarusian & 19 & $8(42.1)$ & $0.62(0.37-1.06)$ & 0.02 \\
\hline Other & 43 & $24(55.8)$ & $0.83(0.63-1.08)$ & 0.12 \\
\hline \multicolumn{5}{|l|}{ Living area } \\
\hline Urban & 428 & $307(71.7)$ & 1.09 (1.00-1.19) & 0.05 \\
\hline Rural & 452 & $297(65.7)$ & 1.0 & \\
\hline \multicolumn{5}{|l|}{ City of residence } \\
\hline Tallinn & 269 & $198(73.6)$ & 1.0 & \\
\hline Tartu & 46 & $27(58.7)$ & $0.80(0.62-1.03)$ & 0.04 \\
\hline Kohtla-Järve & 43 & $33(76.7)$ & $1.04(0.87-1.25)$ & 0.66 \\
\hline Narva & 45 & $30(66.7)$ & $0.91(0.73-1.13)$ & 0.33 \\
\hline Pärnu & 25 & $19(76.0)$ & $1.03(0.82-1.30)$ & 0.79 \\
\hline \multicolumn{5}{|l|}{ Living situation } \\
\hline Permanent home & 804 & $541(67.3)$ & 1.0 & \\
\hline Non-permanent home* & 64 & $54(84.4)$ & $1.25(1.12-1.41)$ & $<0.01$ \\
\hline Homeless ${ }^{\dagger}$ & 42 & $34(81.0)$ & $1.20(1.03-1.40)$ & 0.06 \\
\hline \multicolumn{5}{|l|}{ Level of education $¥$} \\
\hline Primary (4 years) & 61 & $33(54.1)$ & $0.76(0.60-0.97)$ & $<0.01$ \\
\hline Basic (9 years) & 303 & $215(71.0)$ & $1.00(0.91-1.10)$ & 0.99 \\
\hline Secondary (12 years) & 476 & $338(71.0)$ & 1.0 & \\
\hline Higher (>12 years) & 62 & $23(37.1)$ & $0.89(0.73-1.08)$ & 0.19 \\
\hline \multicolumn{5}{|l|}{ Alcohol abuse ${ }^{\S}$} \\
\hline Yes & 421 & $325(77.2)$ & $1.24(1.13-1.35)$ & $<0.001$ \\
\hline No & 464 & $290(62.5)$ & 1.0 & \\
\hline \multicolumn{5}{|l|}{ Drug abuseף } \\
\hline Yes & 65 & $47(72.3)$ & $1.05(0.89-1.23)$ & 0.57 \\
\hline No & 526 & $362(68.8)$ & 1.0 & \\
\hline \multicolumn{5}{|l|}{ History of incarceration } \\
\hline Yes & 171 & $137(80.1)$ & $1.19(1.09-1.30)$ & 0.001 \\
\hline No & 688 & $463(67.3)$ & 1.0 & \\
\hline
\end{tabular}

*Defined as a person staying in random dwellings, with no permanent residence.

$\dagger$ Defined as a person living on the street and/or in shelters.

$¥$ Described as years of school attendance.

$\S$ Regular consumption of alcohol.

"Regular use of drugs.

$\mathrm{RR}=$ risk ratio; $\mathrm{Cl}=$ confidence interval. 
TABLE 3 Clinical characteristics of patients with culture-positive tuberculosis in relation to clusters, Estonia, 2009-2012

\begin{tabular}{|c|c|c|c|c|}
\hline Risk factor & $\begin{array}{c}\text { Total } \\
n\end{array}$ & $\begin{array}{c}\text { Clustered } \\
n(\%)\end{array}$ & RR $(95 \% \mathrm{Cl})$ & $P$ value \\
\hline \multicolumn{5}{|l|}{ Type of TB } \\
\hline Pulmonary & 725 & $513(70.8)$ & 1.0 & \\
\hline Extra-pulmonary & 32 & $8(25.0)$ & $0.35(0.19-0.65)$ & $<0.001$ \\
\hline Both & 148 & $105(70.9)$ & $1.00(0.90-1.12)$ & 0.96 \\
\hline \multicolumn{5}{|l|}{ Category of TB } \\
\hline New & 752 & $507(67.4)$ & 1.0 & \\
\hline Relapse & 100 & $76(76.0)$ & $1.13(1.00-1.27)$ & 0.08 \\
\hline Treatment after failure & 28 & $22(78.6)$ & $1.17(0.95-1.42)$ & 0.22 \\
\hline Treatment after LFU & 32 & $25(78.1)$ & $1.16(0.96-1.40)$ & 0.20 \\
\hline \multicolumn{5}{|l|}{ Drug resistance pattern } \\
\hline Susceptible & 602 & $355(59.0)$ & 1.0 & \\
\hline INH-monoresistant & 15 & $11(73.3)$ & $1.24(0.91-1.70)$ & 0.30 \\
\hline RMP-monoresistant & 7 & $4(57.1)$ & $0.97(0.51-1.85)$ & 1.00 \\
\hline Polyresistant* & 47 & $38(80.9)$ & $1.37(1.18-1.60)$ & $<0.01$ \\
\hline MDR-TB & 144 & $122(91.0)$ & $1.54(1.42-1.68)$ & $<0.001$ \\
\hline $\mathrm{MDR}-\mathrm{TB}+\mathrm{AG} / \mathrm{CP}$ & 54 & $50(92.6)$ & $1.57(1.42-1.74)$ & $<0.001$ \\
\hline MDR-TB+FQ & 26 & $24(92.3)$ & $1.57(1.38-1.78)$ & $<0.001$ \\
\hline XDR-TB & 27 & $26(96.3)$ & $1.63(1.48-1.80)$ & $<0.001$ \\
\hline \multicolumn{5}{|l|}{ HIV testing done } \\
\hline Positive & 107 & $90(84.1)$ & $1.23(1.12-1.36)$ & $<0.001$ \\
\hline Negative & 757 & $517(68.3)$ & 1.0 & \\
\hline
\end{tabular}

* Resistant to at least two of the first-line drugs, but not MDR-TB.

$\mathrm{TB}=$ tuberculosis; $\mathrm{RR}=$ risk ratio; $\mathrm{Cl}=$ confidence interval; $\mathrm{LFU}=$ lost to follow-up; $\mathrm{INH}=$ isoniazid; $\mathrm{RMP}=$ rifampicin; $M D R-T B=$ multidrug-resistant $T B ; A G / C P=$ any of the injectable second-line aminoglycosides or capreomycin; FQ = fluoroquinolone; $\mathrm{XDR}-\mathrm{TB}=$ extensively drug-resistant TB; HIV = human immunodeficiency virus.

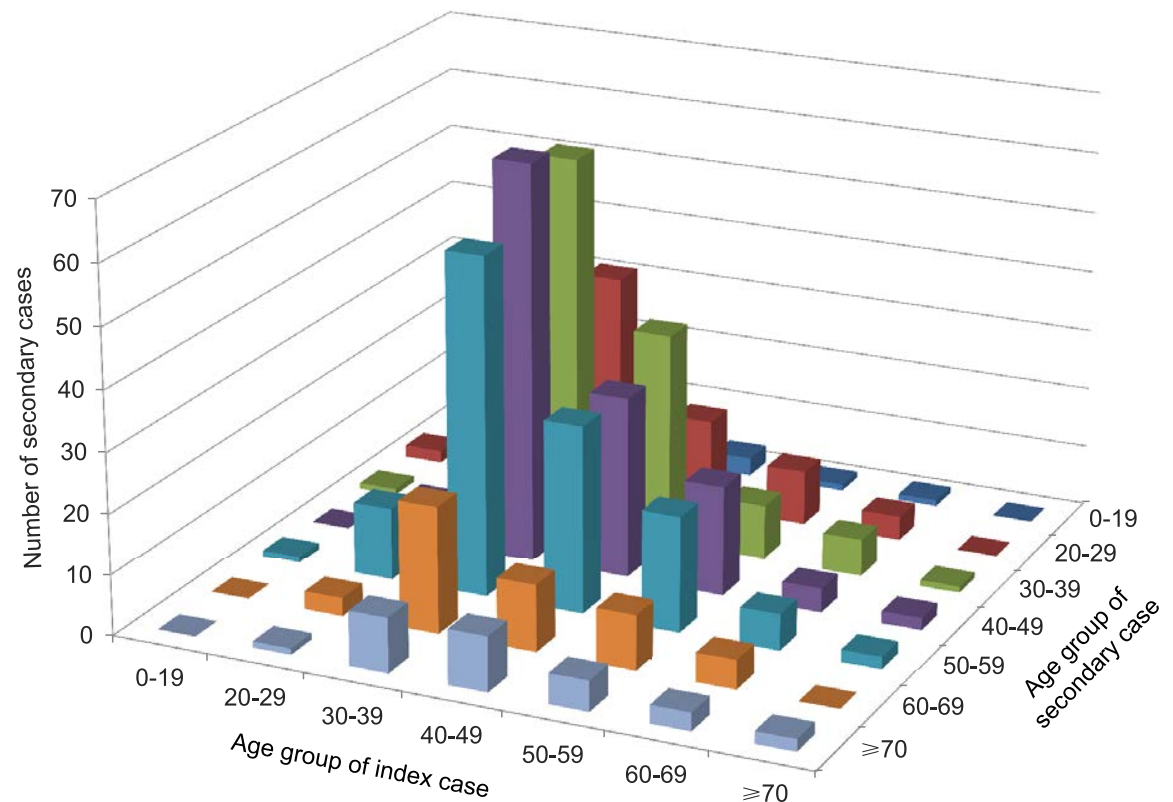

FIGURE 2 Distribution of tuberculosis transmission between age groups of index cases and secondary cases, Estonia, 2009-2012.

jor source of MDR-/XDR-TB in many European Union countries. ${ }^{27}$ In this largest cluster, the prevalence of MDR-/XDR-TB exceeded 90\%. This evidence for active, extensive spread of MDR-/XDR-TB clones of M. tuberculosis Beijing isolates in Estonia is of particular concern, and calls for the need for new measures to better prevent transmission in the populations involved. However, the prominence of this Beijing 100-32 cluster, and of Beijing isolates overall in this setting, means that we must interpret the molecular clus- 
tering results in terms of recent transmission with some caution. Although highly discriminatory, 24-locus VNTR typing lacks resolution power for accurately discriminating closely related clones composing Beijing strain populations in comparison with IS6110RFLP or with the use of additional hypervariable VNTR loci. 8,28 There may thus be some minimal overestimation in our assessment of recent transmission.

Third, we found certain socio-demographic and clinical factors that were significantly associated with clustering, indicating that the clustering detected reflects recent transmission to a good extent. These factors included an absence of a permanent home, alcohol abuse, previous incarceration and having polyresistant TB, MDR- or XDR-TB, or HIV infection. While the associations of clustering with incarceration, alcohol abuse, MDR-/XDR-TB and HIV are well established,29,30 the other socio-demographic associations are novel. However, it makes intuitive sense that those without a permanent home are at increased risk of $\mathrm{TB},{ }^{31}$ and are likely to congregate and spread the infection. We are unaware of previous reports that polyresistant TB is significantly associated with recent transmission. Most of the polyresistant isolates were clustered and were also from the Beijing lineage. This is important because polyresistant Beijing strains are associated with a risk of developing amplified resistance leading to MDR-TB. ${ }^{32}$ Transmission patterns of polyresistant isolates therefore also need to be carefully monitored.

Fourth, we found that certain factors were associated with a reduced risk of recent transmission. Patients with extra-pulmonary $\mathrm{TB}$ had a $65 \%$ reduced risk of recent transmission compared with pulmonary TB patients, and this reflects the predominantly non-infectious nature of extra-pulmonary disease. In patients born in Ukraine, there was a significantly lower risk of clustering, possibly because they acquired latent tuberculous infection in their home country which reactivated after coming to Estonia. Old age was significantly associated with a reduced risk of recent transmission, which may reflect the increasing isolation of elderly people from today's modern society.

The strengths of this study were the large number of patients studied, the countrywide research and the integration of molecular epidemiological data into the TB programme risk factor analysis. The conduct and reporting of the research also followed internationally agreed recommendations for reporting on observational studies. ${ }^{33,34}$

There were two limitations. First, a detailed epidemiological contact investigation was not performed; it therefore remains unclear how person-to-person transmission occurred within each cluster. Second, we used only VNTR typing data for clustering analysis and lineage assignment. Spoligotyping, which is available but not currently in use in Estonia, and additional use of VNTR hypervariable loci on Beijing isolates would have allowed a degree of independent confirmation of lineages and more precise discrimination of cases within clusters, respectively. ${ }^{28,35}$ However, as indicated above, our results from the analysis of risk factors for clustering allows a good degree of confidence in the epidemiological relevance of the clusters identified.

The most important implication of this study is to show the value of molecular epidemiology in understanding the transmission of the TB epidemic in Estonia and, in particular, of the most dangerous MDR-/XDR-TB forms. It will be important to continue to support this field, invest in new molecular epidemiology technology and improve the already good linkages with the NTP.

In conclusion, we have shown that in Estonia, there is a high and perhaps increasing degree of recent TB transmission, especially in certain high-risk groups, and this is particularly associated with MDR- and XDR-TB and the Beijing lineage.

\section{References}

1 World Health Organization. The global plan to stop TB 2011-2015: transforming the fight towards elimination of tuberculosis. Geneva, Switzerland: WHO, 2011.

2 European Centre for Disease Prevention and Control. Tuberculosis surveillance and monitoring in Europe 2014. Stockholm, Sweden: ECDC, 2014.

3 Kliiman K, Altraja A. Predictors of extensively drug-resistant pulmonary tuberculosis. Ann Intern Med 2009; 150: 766-775.

4 van der Zanden A G, Rahim Z, Fedder G, et al. Multiple Mycobacterium tuberculosis infections in an HIV-infected patient. Southeast Asian J Trop Med Public Health 2007; 38: 704-705.

5 van Embden J D, Cave M D, Crawford J T, et al. Strain identification of $\mathrm{Myco}-$ bacterium tuberculosis by DNA fingerprinting: recommendations for a standardized methodology. J Clin Microbiol 1993; 31: 406-409.

6 Supply P, Allix C, Lesjean S, et al. Proposal for standardization of optimized mycobacterial interspersed repetitive unit-variable-number tandem repeat typing of Mycobacterium tuberculosis. J Clin Microbiol 2006; 44: 4498-4510.

7 Allix-Beguec C, Fauville-Dufaux M, Supply P. Three-year population-based evaluation of standardized mycobacterial interspersed repetitive-unit-variable-number tandem-repeat typing of Mycobacterium tuberculosis. J Clin Microbiol 2008; 46: 1398-1406.

8 de Beer J L, van Ingen J, de Vries G, et al. Comparative study of IS6110 restriction fragment length polymorphism and variable-number tandem-repeat typing of Mycobacterium tuberculosis isolates in the Netherlands, based on a 5-year nationwide survey. J Clin Microbiol 2013; 51: 1193-1198.

9 de Beer J L, Kodmon C, van Ingen J, Supply P, van Soolingen D. Second worldwide proficiency study on variable number of tandem repeats typing of Mycobacterium tuberculosis complex. Int J Tuberc Lung Dis 2014; 18: 594 600.

10 Kruuner A, Hoffner S E, Sillastu H, et al. Spread of drug-resistant pulmonary tuberculosis in Estonia. J Clin Microbiol 2001; 39: 3339-3345.

11 Devaux I, Kremer K, Heersma H, Van Soolingen D. Clusters of multidrug-resistant Mycobacterium tuberculosis cases, Europe. Emerg Infect Dis 2009; 15: 1052-1060.

12 Cirillo D. TB PAN-NET: Pan-European network for study and clinical management of drug resistant tuberculosis. Milan, Italy: TB PAN-NET, 20092013.

13 Tiit Eesti Matemaatika Selts. The census of people and housing. Overview of the population in Estonian counties. Tallinn, Estonia: Data Protection Agency, 2013.

14 World Health Organization. Multidrug and extensively drug-resistant TB (M/XDR-TB): 2010 global report on surveillance and response. WHO/HTM/ TB/2010.3. Geneva, Switzerland: WHO, 2010.

15 World Health Organization. Treatment of tuberculosis: guidelines. $4^{\text {th }}$ ed. WHO/HTM/TB/2009.420. Geneva, Switzerland: WHO, 2009.

16 Rüsch-Gerdes S, Pfyffer G E, Casal M, Chadwick M, Siddiqi S. Multicenter laboratory validation of the BACTEC MGIT 960 technique for testing susceptibilities of Mycobacterium tuberculosis to classical second-line drugs and newer antimicrobials. J Clin Microbiol 2006; 44: 688-692.

17 World Health Organization. Policy guidance on drug-susceptibility testing (DST) of second-line antituberculosis drugs. WHO/HTM/TB/2008.392. Geneva, Switzerland: WHO, 2008.

18 Cowan L S, Hooks D P, Christianson S, et al. Evaluation of mycobacterial interspersed repetitive-unit-variable-number tandem-repeat genotyping as performed in laboratories in Canada, France, and the United States. J Clin Microbiol 2012; 50: 1830-1831; author reply 1832.

19 Weniger T, Krawczyk J, Supply P, Niemann S, Harmsen D. MIRU-VNTRplus: a web tool for polyphasic genotyping of Mycobacterium tuberculosis complex bacteria. Nucleic Acids Res 2010; 38: W326-331.

20 Sokal R R, Michener C D. A statistical method for evaluating systematic relationships. Univ Kansas Sci Bull 1958; 38: 1409-1438.

21 Allix-Beguec C, Niemann S, Weniger T, Supply P, Harmsen D. Automated web based identification of Mycobacterium tuberculosis genotypes: Evaluation and user-strategy of the MIRU-VNTRplus database. J Clin Microbiol 2008; 298: 93.

22 Saitou N, Nei M. The neighbor-joining method - a new method for reconstructing phylogenetic trees. Mol Biol Evol 1987; 4: 406-425

23 Allix-Beguec C, Harmsen D, Weniger T, Supply P, Niemann S. Evaluation and strategy for use of MIRU-VNTRplus, a multifunctional database for online analysis of genotyping data and phylogenetic identification of Mycobacterium tuberculosis complex isolates. J Clin Microbiol 2008; 46: 2692-2699.

24 Mokrousov I, Jiao W W, Sun G Z, et al. Evolution of drug resistance in different sublineages of Mycobacterium tuberculosis Beijing genotype. Antimicrob Agents Chemother 2006; 50: 2820-2823.

25 Glynn J R, Kremer K, Borgdorff M W, Rodriguez M P, van Soolingen D, Euro- 
pean concerted action N. Beijing/W genotype Mycobacterium tuberculosis and drug resistance. Emerg Infect Dis 2006; 12: 736-743.

26 World Health Organization. Multidrug-resistant TB (MDR-TB): 2013 update. Geneva, Switzerland: WHO, 2013. http://www.who.int/tb/challenges/mdr/ mdr_tb_factsheet.pdf?ua=1 Accessed August 2014.

27 De Beer J L, Kodmon C, van der Werf M J, van Ingen J, van Soolingen D, the ECDC MDR-TB molecular surveillance project participants. Molecular surveillance of multi-and extensively drug-resistant tuberculosis transmission in the European Union from 2003 to 2011. Euro Surveill 2014; 19: pii: 20742.

28 Allix-Beguec C, Wahl C, Hanekom M, et al. Proposal of a consensus set of hypervariable mycobacterial interspersed repetitive-unit-variable-number tandem-repeat loci for subtyping of Mycobacterium tuberculosis Beijing isolates. J Clin Microbiol 2014; 52: 164-172.

29 Alland D, Kalkut G E, Moss A R, et al. Transmission of tuberculosis in New York City: an analysis by DNA-fingerprinting and conventional epidemiologic methods. N Engl J Med 1994; 330: 1710-1716.

30 Mokrousov I, Valcheva V, Sovhozova N, Aldashev A, Rastogi N, Isakova J. Penitentiary population of Mycobacterium tuberculosis in Kyrgyzstan: Excep- tionally high prevalence of the Beijing genotype and its Russia-specific subtype. Infect Genet Evol 2009; 9: 1400-1405.

31 Lönnroth K, Jaramillo E, Williams B G, Dye C, Raviglione M. Drivers of tuberculosis epidemics: the role of risk factors and social determinants. Soc Sci Med 2009; 68: 2240-2246.

32 Cox H S, Niemann S, Ismailov G, et al. Risk of acquired drug resistance during short-course directly observed treatment of tuberculosis in an area with high levels of drug resistance. Clin Infect Dis 2007; 44: 14211427.

33 von Elm E, Altman D G, Egger M, et al. The Strengthening the Reporting of Observational Studies in Epidemiology (STROBE) statement: guidelines for reporting observational studies. Ann Intern Med 2007; 370: 1453-1457.

34 Edginton M, Enarson D, Zachariah R. Why ethics is indispensible for good-quality operational research. Public Health Action 2012; 2: 21-22.

35 Oelemann M C, Diel R, Vatin V, et al. Assessment of an optimized mycobacterial interspersed repetitive-unit-variable-number tandem-repeat typing system combined with spoligotyping for population-based molecular epidemiology studies of tuberculosis. J Clin Microbiol 2007; 45: 691-697.
Public Health Action (PHA) The voice for operational research. Published by The Union (www.theunion.org), PHA provides a platform to fulfil its mission, 'Health solutions for the poor'. PHA publishes high-quality scientific research that provides new knowledge to improve the accessibility, equity, quality and efficiency of health systems and services.
e-ISSN 2220-8372

Editor-in-Chief: Donald A Enarson, MD, Canada

Contact: pha@theunion.org

PHA website: http://www.theunion.org/index.php/en/journals/pha Article submission: http://mc.manuscriptcentral.com/pha 


\section{Четырехлетнее общенациональное молекулярное эпидемиологическое исследование в Эстонии: факторы риска трансмиссии туберкулеза}

\author{
K. Toit, ${ }^{1,2}$ A. Altraja, ${ }^{2,3}$ C. D. Acosta, ${ }^{4}$ P. Viiklepp ${ }^{5}$ K. Kremer, ${ }^{4,6}$ T. Kummik, ${ }^{1}$ M. Danilovitš, ${ }^{3}$ R. Van den Bergh, ${ }^{7}$ \\ A. D. Harries, 8,9 P. Supply $10,11,12,13$
}

http://dx.doi.org/10.5588/pha.14.0045

МЕСТО ПРОВЕДЕНИЯ: В ЭстониИ отмечается большое чИсло случаев туберкулеза с множественной лекарственной устойчивостью (МЛУ-ТБ). Для того чтобы понять пути трансмиссии ТБ важно сопоставить молекулярные и эпидемиологические данные.

ЦЕЛЬ: Использовать результаты анализа числа тандемных повторов в 24-х локусах генома (VNTR-типирование) и данные национального ТБ регистра Эстонии за период с 2009г. по 2012г. с целью определения распределения спектров лекарственной устойчивости, кластеров изолятов Mycobacterium tuberculosis как показателя их недавней трансмиссии, социально-демографических и клинических характеристик, связанных с недавней трансмиссией, а также изучения распределения трансмиссии между индексным-пациентом и вторичными случаями.

ДИЗАЙН: Ретроспективное общенациональное перекрестное исследование.

РЕЗУЛЬТАТЫ: Было рассмотрено 912 случаев ТБ, по которым имелись данные о больном и изоляте; 39,1\% выделенных у этих больных изолятов принадлежали к семействy Beijing. Кластерный анализ выявил 87 кластеров, объединяющих 69,1\% изолятов. Самый большой кластер состоял из 178 изолятов, принадлежащих семейству Beijing, из которых 92,1\% имели МЛУ или широкую лекарственную устойчивостью (ШЛУ). Факторы, связанные с недавней трансмиссией, включали: полирезистентный ТБ, МЛУ- и ШЛУ-ТБ, наличие вируса иммунодефицита человека, русскую национальность, отсутствие постоянного места жительства, злоупотребление алкоголем и пребывание в местах лишения свободы. Самый высокий риск недавней трансмиссии наблюдался в случаях ШЛУ-ТБ. Большинство случаев трансмиссии приходилось на лиц в возрасте 30-39 лет.

ВЫВОД: Показатель недавней трансмиссии ТБ в Эстонии остается высоким и главным образом связан с МЛУ-ТБ, ШЛУ-ТБ и семейством Beijing.

\footnotetext{
амая маленькая страна Балтии - Эстония (население 1,3 миллиона человек) страдает от одних из самых высоких показателей по туберкулезу (ТБ) в Европейском регионе и принадлежит к числу 27 стран мира с высоким бременем туберкулеза с множественной лекарственной устойчивостью (МЛУ-ТБ). ${ }^{1}$ Заболеваемость ТБ уменьшилась с 36,6 на 100000 населения в 2007г. до 21,6/100 000 в 2012г. Однако четверть $(25,5 \%)$ из 234 впервые выявленных больных ТБ, зарегистрированных в 2012г, имели МЛУТБ (устойчивость минимум к изониазиду и рифампицину [RMP]), из них 6,6\% имели ТБ с широкой лекарственной устойчивостью (ШЛУ-ТБ - МЛУ-ТБ плюс устойчивость к фторхинолону и одному из трех инъекционных препаратов). ${ }^{2}$ Проведенные недавно в Эстонии исследования показали, что вирус иммунодефицита человека (ВИЧ), отсут-
}

ствие постоянного места жительства и злоупотребление алкоголем существенно повышают риск развития ШЛУТБ. ${ }^{3}$ Однако то, насколько эти детерминанты способствуют трансмиссии ТБ неизвестно.

Молекулярная эпидемиология внесла существенный вклад в понимание механизмов трансмиссии ТБ. Исследования с использованием данного подхода помогли определить долю случаев активного ТБ, вызванных реинфицированием или реактивацией, а также определить факторы риска трансмиссии ТБ в сообществах. ${ }^{4}$ Наиболее часто используемым в подобных исследованиях методом ДНК- отпечатков пальцев Mycobacterium tuberculosis является типирование по полиморфизму длин рестрикционных фрагментов, содержащих инсерционную последовательность (IS) 6110 (RFLP-типирование) ${ }^{5}$ и анализ числа тандемных повторов в 24-х локусах (VNTR-типирование), 6 которые были международно стандартизованы в 1993г. и 2006г., соответственно. VNTR-типирование имеет ряд серьезных преимуществ по сравнению с RFLP-типированием, включая простоту его проведения, короткое время до получения результата и цифровой формат вывода результата. Кроме того, ряд популяционных исследований показал, что в ряде стран Западной Европы прогностическая ценность результатов VNTR-типирования для изучения трансмиссии ТБ аналогична прогностической ценности RFLP-типирования.7,8 Действующим золотым стандартом в молекулярной эпидемиологии ТБ является именно VNTR-типирование, результатом которого является число копий соответствующего повтора, позволяющее провести идентификацию штаммов M. tuberculosis. 9 Предполагается, что больные, инфицированные изолятами M. tuberculosis, имеющими идентичные ДНК-отпечатки пальцев, 1) инфицированы одинаковым штаммом M. tuberculosis и 2) инфицировали друг друга, имеют один источник инфекции или были независимо инфицированы штаммом, превалирующим в данном сообществе. И наоборот, предполагается, что больные, инфицированные штаммом, имеющим уникальный в популяции ДНК-отпечаток, либо страдают от реактивации инфекции, либо были инфицированы штаммом недавно привнесенным в сообщество этим больным. Исследователи использовали молекулярную кластеризацию, а именно совпадение идентичных ДНК-отпечатков, в качестве показателя трансмиссии ТБ.

Первое исследование с использованием результатов RFLP ДНК-отпечатков пальцев, проведенное в Эстонии, показало высокие показатели кластеризации изолятов МЛУ-ТБ и предположило наличие связи между генотипом Beijing M. tuberculosis и лекарственной устойчивостью. ${ }^{10}$
УЧРЕЖДЕНИЯ 1 Объединенны лаборатории Университетская больниц Тарту, Тарту, Эстония 2 Кафедра пульмонологии, Университет Тарту, Тарту, Эстония

3 Легочная клиника, Университетская больница Тарту, Тарту, Эстония

4 Программа борьбыс туберкулезом и М/ШЛУ-ТБ, Отдел инфекционных заболеваний, безопасности здоровья и окружающей среды, Европейское

региональное бюро ВО3, региональное бюро
Копенгаген, Дания

5 Национальный институт развития здоровья, Таллинн, Эстония

6 Центр по контролю инфекционных инфекционных Наболеваний, общественного здоровья и окружающей среды, Билтховен, Нидерланды

7 Медицинский отдел, Брюссельский операционный центр, Médecins Sans Frontières MSF-Люксембург, Люксембург

8 Международный союз по борьбе с туберкулезом и болезнями легких, Париж, Франция

9 Лондонская школа гигиены и тропической медицины, Лондон, Великобритания 10 Institut National de la Santé et de la Recherche Santé et de la Recherch Médicale 1019, Лилл Франция

1 Unites Mixtes de Recherche 8204, Centre national de la Recherch scientifique, Лиль, Франция

12 Лилльский центр изучения инфекций и иммунитета, Институт Пастера, Лилль, Франция

13 Университет Северной Франции, Лилль, Франция

Контактное лицо

для переписки Kadri Toit, Department of Mycobacteriology

United Laboratories Tartu University Hospital Puusepa 1a

50406 Tartu, Estonia

Tel: (+372) 7428262 e-mail: Kadri.Toit@kliinikum.ee

КЛЮЧЕВЫЕ СЛОВА:

семейство Beijing;

кластеризация; МЛУ-ТБ; SORT

IT; операционное исследование

Статья подана

4 мая 2014.

Окончательный вариант принят 27 июля 2014.

PHA 2014; 4(3): S37-S43 (C) 2014 The Union 
Последующее исследование, сравнивавшее ДНК-отпечатки пальцев случаев МЛУ-ТБ, зарегистрированных в Европе в период 2003-2007гг, показало, что штаммы Beijing преобладали в Эстонии и являлись частью более крупного кластера штаммов МЛУ-ТБ (кластера Е0051), обнаруженного в 12 разных странах. ${ }^{11}$ В 2009г. в Эстонии было начало использование VNTR-типирования в рамках проекта «TB PAN-NET»;12 одной из целей которого было изучение трансмиссии ТБ в странах Европы.

В рамках данного исследования использовались результаты VNTR-типирования, полученные в ходе проекта «TB PAN-NET», для построения базы данных, которая была подключена к Эстонскому национальному ТБ регистру (НТР) для содействия мероприятиям по борьбе с ТБ. В частности, мы провели кластерный анализ ДНК-отпечатков пальцев с целью выявления групп риска, в отношении которых НПТ могут быть приняты меры для улучшения профилактики трансмиссии ТБ.

\section{МЕТОДЫ}

Дизайн исследования

Это было ретроспективное общенациональное перекрестное исследование.

Место проведения

Эстония - небольшая страна в Европе, соседствующая с Латвией, Финляндией и Российской Федерацией, с населением около 1,3 миллиона человек. Около $30 \%$ населения проживает в столице - Таллинне. ${ }^{13}$ Около 70\% населения - эстонцы, 25\% - русские, оставшиеся 5\% включают различные этнические группы из бывшего СССР и Восточной Европы.

С 1998г. учреждения, занимающиеся лечением туберкулеза в Эстонии, следуют рекомендациям НПТ, которые соответствуют рекомендациям Всемирной организации здравоохранения. ${ }^{14}$ Преобладает пассивное выявление случаев ТБ; постановка диагноза ТБ легких основана на микроскопии мазка мокроты, посеве и рентгенографии органов грудной клетки, для диагностики внелегочного туберкулеза используются и другие методы исследований. Все больные ТБ регистрируются в НПТ с присвоением им уникального регистрационного номера, проходят стандартизованное, главным образом, стационарное лечение с мониторингом исходов в соответствии с национальными и международными рекомендациями. ${ }^{15}$ Все услуги по диагностике и лечению ТБ и при необходимости опиоидная заместительная терапия (ОЗП) в стране предоставляются бесплатно.

\section{Выборка пациентов}

Все больные с положительной культурой, результатами ТЛЧ и VNTR-типирования в период с января 2009г. по декабрь 2012г. были включены в исследование.

\section{Источники и сбор данных}

В Эстонии действуют две лаборатории, выполняющие культуральные исследования ТБ: одна в Таллинне и ТБ референс-лаборатория в Тарту. С целью диагностики ТБ все образцы в стране отправляются в одну из двух этих лабораторий. Все положительные культуры исследуются на лекарственную чувствительность к препаратам первого ряда (ТЛЧ) 16 и, при наличии устойчивости к препаратам первого ряда проводятся ТЛЧ к препаратам второго ряда. ${ }^{17}$ ТБ референс-лаборатория в Тарту архивирует все изоляты ТБ, имеющие результаты ТЛЧ, и отвечает за проведение ДНК генотипирования. В рамках проекта «ТВ PAN-NET» генотипирование ДНК изолята проводилось Институтом Пастера (Лилль, Франция) стандартным методом VNTR-типирования6 и с помощью наборов для VNTR-типирования микобактериальных рассеянных повторяющихся единиц (MIRU) фирмы Genoscreen (Лилль, Франция). Осуществлялся строгий контроль качества типирования с помощью включения положительного (ДНК М. bovis bacille Calmette-Guérin) и отрицательного контролей и внутренних процедур. При проведении независимой оценки качества VNTR-типирования данная лаборатория всегда получала 100\% баллов за внутри- и межлабораторную воспроизводимость результатов.9,18 База данных VNTR-паттернов всех случаев с положительной культурой хранится в Референс-лаборатории в Тарту.

Все характеристики больных и демографические данные брались из Эстонского HTP. VNTR- паттерны запрашивались в ТБ референс-лаборатории, а результаты ТЛЧ в HТP. Данные из разных источников увязывались с помощью уникальных параметров: ФИО и даты рождения больных. Данные из связанных баз данных поступали в базу данных EpiData (EpiData Association, Оденсе, Дания).

Анализ данных и статистический анализ

Кластерный анализ VNTR-паттернов и определение генетического семейства проводился с помощью базы данных MIRU-VNTRplus. ${ }^{19}$ Кластерный анализ проводился методом попарного невзвешенного кластирования с арифме тическим усреднением (UPGMA) с использованием категориального коэффициента. ${ }^{20}$ Кластером считались минимум два изолята со 100\% идентичными паттернами VNTR-типирования. Индексным случаем считался хронологически первый случай в кластере. Кластеризация VNTR-паттернов использовалась в качестве меры трансмиссии ТБ. Определение генетического семейства проводилось поиском сходства, предусмотренным в базе данных MIRU-VNTRplus, с использованием максимального генотипического расстояния 0,17 и древоподобной модели идентификации на основе алгоритма объединения ближайших соседей. ${ }^{21,22}$

Число и размер кластеров, а также их генетические характеристики были представлены в виде таблицы. Была изучена связь между различными характеристиками больных и кластеризацией изолятов, были рассчитаны отношения рисков (ОР) и соответствующие 95\% довери тельные интервалы (ДИ). Различия на уровне 5\% (P < 0,05), полученные с помощью критерия Пирсона Х2, считались статистически значимыми. Все данные анализировались с помощью пакета EpiData версия 2.2.2.182 (EpiData Association)

\section{Одобрение комитетом по этике}

Было получено одобрение Исследовательского комитета по этике Университета Тарту, Тарту, Эстония и Консультативной группы по вопросам этики Международного союза по борьбе с туберкулезом и заболеваниями легких Париж, Франция. Разрешение на сбор, обработку и анализ данных больных было получено от Эстонской инспекции по защите данных и от Министерства социального развития, Таллинн, Эстония.
Выражение благодарности Данное исследование было Инициативе по порготов йливке структурирова

струкурированных глобального партнерств возглавляемого Специальной программой по научным исследованиям и подготовке специалистов в области тропических заболеваний Всемирной организации здравоохранения (BO3/TDR, Женева, Швейцария). Специальная программа SORT IT, результатом которой стала данная публикация, была совместно разработа ирепейски регионан

боро ВОЗ Копенгаген, Дания (2) итделом операционных Médecins Sans Frontières, Брюссельского

операционного центра, Люксембург; Центром операционных исследований, Международного союза борьбы с ТБ и заболеваниями легких (The Union), Париж,

Франция;

представительством Союза в Юго-Восточной Азии, Нью Дели, Индия.

Мы благодарны за поддержку страновому офису ВО3 в Мали й (2) (Торовья и развития проведение рабочих совещаний. Мы также высоко ценим активное участие странового офиса ВО3 и Министерства

здравоохранения (Таллинн, Эстония) в выборе кандидатов для подготовки проведению операционных исследований и определении исследовательских проектов. Финансирование данного исследования

Существлялось в рамках Седьмой рамочной Крограммы Европейского (рантового 7/2007-2013) FP7-223681. Программа SORT IT финансировалась Американским агентством международного развития (Вашингтон округ Колумбия, США) посредством гранта, управление которым осуществляла программа BO3-TDR. Дополнительная помощь была предоставлена Европейским региональным бюро ВО3, Департаментом международного развити (Лондан, Соединенное Врачи без границгнизацией Финансирующие стор рар дизайна, сборе и анализ дайна, с принятии реше о публикации или подготовке стать

Конфликт интересов: PS является консультантом Genoscreen. Другие авторы о конфликте интересов не

заявляли.

В соответствии с политикой ВОЗ в отношении публикаци для открытого доступа всех работ, финансируемых ВО3 или авторами/соавторами которых выступают сохраняет авторское право на данную публикациюн основании лицензии Creative Commons Attribution (http:// creativecommons.org/licenses/ by/3.0/igo/legalcode), разрешающей неограниченное использование материала, его распространение и воспроизведение на любых ресурсах с указанием ссылки на ВОЗ в качестве источника информации.

Только авторы несут ответственность за точку рени, выражену в даннй публиции, которая политику решения или точку Политику, ре 
ТАБЛИЦА 1 Спектры лекарственной устойчивости изолятов, выделенных у больных ТБ с положительным посевом, и их распределение по генетическим семействам, Эстония, 2009-2012гг.

\begin{tabular}{|c|c|c|c|c|c|c|c|}
\hline \multirow[b]{2}{*}{ Спектр устойчивости } & \multirow[b]{2}{*}{$\begin{array}{c}\text { Всего } \\
n\end{array}$} & \multicolumn{6}{|c|}{ Доля семейств M. tuberculosis } \\
\hline & & $\begin{array}{c}\text { Beijing } \\
n(\%)\end{array}$ & $\begin{array}{c}\text { Haarlem } \\
n(\%)\end{array}$ & $\begin{array}{l}\text { LAM } \\
n(\%)\end{array}$ & $\begin{array}{l}\text { Ural } \\
n(\%)\end{array}$ & $\begin{array}{c}\text { Неизвестно } \\
n(\%)\end{array}$ & $\begin{array}{c}\text { Прочее } \\
n(\%)\end{array}$ \\
\hline Чувствительный & 602 & $101(16.8)$ & $168(27.9)$ & $131(21.8)$ & $72(12.0)$ & $122(20.3)$ & $8(1.4)$ \\
\hline INH-монорезистентный & 15 & $2(13.3)$ & $4(26.7)$ & $6(40.0)$ & - & $3(20.0)$ & - \\
\hline RMP-монорезистентный & 7 & $1(14.3)$ & - & $5(71.4)$ & - & $1(14.3)$ & - \\
\hline Полирезистентный* & 47 & $30(63.8)$ & $2(4.3)$ & $7(14.9)$ & $8(17.0)$ & - & - \\
\hline МлУ-ТБ & 134 & $126(94.0)$ & $2(1.5)$ & $3(2.2)$ & $3(2.2)$ & - & - \\
\hline МЛУ-ТБ+AG/CP & 54 & $45(83.3)$ & - & $9(16.7)$ & - & - & - \\
\hline МЛУ-ТБ+FQ & 26 & $26(100.0)$ & - & - & - & - & - \\
\hline шлУ-ТБ & 27 & $26(96.3)$ & - & $1(3.7)$ & - & - & - \\
\hline Итого & 912 & $357(39.2)$ & $176(19.3)$ & $162(17.8)$ & $83(9.1)$ & $126(13.8)$ & $8(0.8)$ \\
\hline
\end{tabular}

* Устойчивость минимум к двум препаратам первого ряда, но не МЛУ-ТБ.

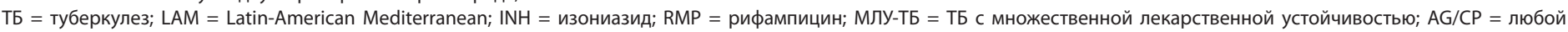
инъекционный аминогликозид второго ряда или капреомицин;

FQ = фторхинолон; ШЛУ-ТБ = ТБ с широкой лекарственной устойчивостью.

\section{РЕЗУЛЬТАТЫ}

Из 1371 больного ТБ, выявленного в Эстонии в течение 4-х летнего периода проведения исследования, 1286 (93,8\%) имели ТБ легких, 1080 (78.8\%) были выявлены впервые и ранее не получали лечение противотуберкулезными препаратами, 1066 (77,8\% от общего числа) имели положительные культуры. Из них у 917 (86,0\%) больных в базе данных Национальной референс-лаборатории хранились VNTR-паттерны выделенных изолятов. Удалось проследить связь между больным и информацией о выделенных у него изолятах в 912 случаях, включая девять больных, зарегистрированных дважды в результате возобновления ТБ.

Удалось определить принадлежность к генетическому семейству $86,2 \%$ из 912 изолятов (случаев). Распределение семейств в зависимости от спектра ТЛЧ представлено в таблице 1. Самая большая доля изолятов ( $\mathrm{n}=357 ; 39,2 \%)$ принадлежала к семейству Beijing. Лекарственно чувствительные изоляты были равномерно распределены по четырем основным семействам (Beijing, Haarlem, Latin-AmericanMediterranean [LAM] и Ural). Напротив, большинство изолятов МЛУ- и ШЛУ-ТБ принадлежали к семейству Beijing (94,0\% и 96,3\%, соответственно). Помимо этого, пять из семи изолятов с RMP-монорезистентностью $(71,4 \%)$ принадлежали семейству LAM.

Всего было выделено 87 кластеров, объединяющих 630 (69,1\%) изолятов (рис. 1). Десять кластеров состояли из более чем 10 изолятов, четыре кластера насчитывали более 20 изолятов. Самый большой кластер состоял из 178 изолятов штамма MtbC 15-9 типа 100-32 семейства Beijing по номенклатуре стандартного VNTR-типирования; 21,23164 $(92,1 \%)$ из них были МЛУ- или ШЛУ-ТБ. Напротив, второй по величине кластер состоял из 32 изолятов, относящихся к семейству LAM, 30 $(94,0 \%)$ из которых были лекарственно чувствительными. Третий по величине кластер состоял из 30 изолятов другого штамма семейства Beijing (MtbC 15-9 тип 94-32), 9 (30,0\%) из них имели МлУ или Шлу.

Социально-демографические факторы, связанные с повышенным риском формирования кластера включали русскую национальность, отсутствие постоянного места жительства, злоупотребление алкоголем и пребывание в прошлом в местах лишения свободы; к факторам, связанным с меньшим риском формирования кластеров, относились: пожилой возраст, место рождения - Украина, принадлежность в белорусской национальности, проживание в Тарту и низкий уровень образования (таблица 2). Клиническими факторами, связанными с повышенным риском кластеризации, были полирезистентность, МЛУ- и ШЛУ-ТБ, а также наличие ВИЧ инфекции (таблица 3). Случаи шЛУ-ТБ
-ТВ были подвержены наибольшему риску образования кластера (ОР 1,63, Р < 0,001). Внелегочный ТБ был связан с меньшим риском образования кластера.

Распределение трансмиссии между индексными случаями и вторичными случаями по разным возрастным группам представлено на рис. 2. Чаще всего трансмиссия отмечалась в возрастной группе 30-39 лет. Большинство вторичных случаев приходилось на лиц в возрасте 30-59 лет.

\section{ОБСУЖДЕНИЕ}

Это первое молекулярно-эпидемиологическое исследование, использовавшее метод VNTR-типирования для изучения связи между больными, их характеристиками, штаммами M. tuberculosis и образованием кластеров с целью определения, имела ли место недавняя трансмиссия ТБ. В ходе исследования был сделан ряд важных выводов.

Во-первых, преобладали штаммы, относящиеся к семейству Beijing, которые были особенно связаны с лекарственной устойчивостью ТБ. Более 90\% больных МЛУ-ТБ, МЛУ-ТБ с дополнительной устойчивостью к препаратам второго ряда и ШЛУ-ТБ были инфицированы штаммами, относящимися к семейству Beijing. Связь между тяжелой лекарственной устойчивостью и принадлежностью к семейству Beijing хорошо известна во всем мире; 24,25 в Эстонии эта связь также была доказана в 2001г. на примере изолятов от 1994г.10 Таким образом, наши данные демонстрируют непрерывную, многолетнюю стой-

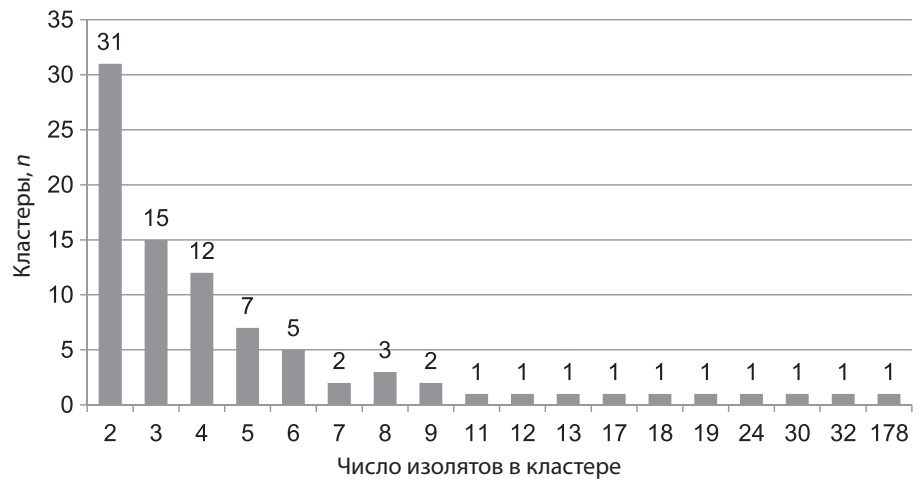

РИСУНОК 1 Число и размер кластеров у больных туберкулезом с положительной культурой, Эстония, 2009-2012. 
ТАБЛИЦА 2 Социально-демографические характеристики больных туберкулезом с положительным посевом в зависимости от кластеров, Эстония, 2009-2012

\begin{tabular}{|c|c|c|c|c|}
\hline Фактор риска & $\begin{array}{c}\text { Всего } \\
n\end{array}$ & $\begin{array}{c}\text { Составляют класте } \\
n(\%)\end{array}$ & ОР (95\%ДИ) & Рзначение \\
\hline \multicolumn{5}{|l|}{ Пол } \\
\hline Мужской & 638 & $449(70.4)$ & $1.07(0.97-1.18)$ & 0.20 \\
\hline Женский & 274 & $181(66.0)$ & 1.0 & \\
\hline \multicolumn{5}{|l|}{ Возраст, лет } \\
\hline+20 & 16 & $12(75.0)$ & $1.01(0.75-1.35)$ & 1.0 \\
\hline $20-29$ & 110 & $91(82.7)$ & $1.11(0.99-1.25)$ & 0.10 \\
\hline $30-39$ & 178 & $144(80.9)$ & $1.09(0.97-1.21)$ & 0.14 \\
\hline $40-49$ & 200 & $149(74.5)$ & 1.0 & \\
\hline $50-59$ & 198 & $142(71.7)$ & $0.96(0.85-1.08)$ & 0.53 \\
\hline $60-69$ & 101 & $59(58.4)$ & $0.78(0.65-0.94)$ & +0.01 \\
\hline$\geq 70$ & 109 & $33(30.3)$ & $0.41(0.30-0.55)$ & +0.001 \\
\hline \multicolumn{5}{|l|}{ Страна рождения } \\
\hline Эстония & 772 & $550(71.2)$ & 1.0 & \\
\hline Россия & 96 & $62(64.6)$ & $0.91(0.78-1.06)$ & 0.18 \\
\hline Украина & 15 & $4(26.7)$ & $0.37(0.16-0.87)$ & +0.001 \\
\hline Беларусь & 11 & $6(54.5)$ & $0.77(0.45-1.32)$ & 0.23 \\
\hline \multicolumn{5}{|l|}{ Этническая принадлежность } \\
\hline Эстонец & 515 & $348(67.6)$ & 1.0 & \\
\hline Русский & 320 & $242(75.6)$ & $1.12(1.03-1.22)$ & 0.01 \\
\hline Беларусь & 19 & $8(42.1)$ & $0.62(0.37-1.06)$ & 0.02 \\
\hline Прочее & 43 & $24(55.8)$ & $0.83(0.63-1.08)$ & 0.12 \\
\hline \multicolumn{5}{|l|}{ Место жительства } \\
\hline Город & 428 & $307(71.7)$ & $1.09(1.00-1.19)$ & 0.05 \\
\hline Село & 452 & $297(65.7)$ & 1.0 & \\
\hline \multicolumn{5}{|l|}{ Город проживания } \\
\hline Таллинн & 269 & $198(73.6)$ & 1.0 & \\
\hline Тарту & 46 & $27(58.7)$ & $0.80(0.62-1.03)$ & 0.04 \\
\hline Кохтла-Ярве & 43 & $33(76.7)$ & $1.04(0.87-1.25)$ & 0.66 \\
\hline Нарва & 45 & $30(66.7)$ & $0.91(0.73-1.13)$ & 0.33 \\
\hline Парну & 25 & $19(76.0)$ & $1.03(0.82-1.30)$ & 0.79 \\
\hline \multicolumn{5}{|l|}{ Условия проживания } \\
\hline Постоянное место жительства & 804 & $541(67.3)$ & 1.0 & \\
\hline $\begin{array}{l}\text { Непостоянное место } \\
\text { жительства* }\end{array}$ & 64 & $54(84.4)$ & $1.25(1.12-1.41)$ & +0.01 \\
\hline БОМж ${ }^{+}$ & 42 & $34(81.0)$ & $1.20(1.03-1.40)$ & 0.06 \\
\hline \multicolumn{5}{|l|}{ Уровень образования ${ }^{\ddagger}$} \\
\hline Начальное (4 года) & 61 & $33(54.1)$ & $0.76(0.60-0.97)$ & +0.01 \\
\hline Основное (9 лет) & 303 & $215(71.0)$ & $1.00(0.91-1.10)$ & 0.99 \\
\hline Среднее (12 лет) & 476 & $338(71.0)$ & 1.0 & \\
\hline Высшее (>12 лет) & 62 & $23(37.1)$ & $0.89(0.73-1.08)$ & 0.19 \\
\hline \multicolumn{5}{|l|}{ Алкогольная зависимость $\$$} \\
\hline Да & 421 & $325(77.2)$ & $1.24(1.13-1.35)$ & +0.001 \\
\hline нет & 464 & $290(62.5)$ & 1.0 & \\
\hline \multicolumn{5}{|l|}{ Наркотическая зависимость" } \\
\hline Да & 65 & $47(72.3)$ & $1.05(0.89-1.23)$ & 0.57 \\
\hline Нет & 526 & $362(68.8)$ & 1.0 & \\
\hline \multicolumn{5}{|l|}{$\begin{array}{l}\text { Пребывание в местах лишения } \\
\text { свободы }\end{array}$} \\
\hline Да & 171 & $137(80.1)$ & $1.19(1.09-1.30)$ & 0.001 \\
\hline Нет & 688 & $463(67.3)$ & 1.0 & \\
\hline
\end{tabular}

* Лицо, проживающее по разным адресам, без постоянного места жительства.

† Лицо, проживающее на улице и/или приюте.

‡ Количество лет посещения учебных заведений.

$\S$ Регулярное потребление алкоголя.

ף Регулярное употребление наркотиков.

ОР = отношение рисков; ДИ = доверительный интервал. 
ТАБЛИЦА 3 Клинические характеристики больных туберкулезом с положительной культурой в зависимости от кластеров, Эстония, 2009-2012rr.

\begin{tabular}{|c|c|c|c|c|}
\hline Фактор риска & $\begin{array}{c}\text { Всего } \\
n\end{array}$ & $\begin{array}{c}\text { Входят в кластеры } \\
n(\%)\end{array}$ & ОР (95\%ДИ) & Рзначение \\
\hline \multicolumn{5}{|l|}{ Тип ТБ } \\
\hline Легочный & 725 & $513(70.8)$ & 1.0 & \\
\hline Внелегочный & 32 & $8(25.0)$ & $0.35(0.19-0.65)$ & +0.001 \\
\hline Оба & 148 & $105(70.9)$ & $1.00(0.90-1.12)$ & 0.96 \\
\hline \multicolumn{5}{|l|}{ Категория ТБ } \\
\hline Впервые выявленный & 752 & $507(67.4)$ & 1.0 & \\
\hline Рецидив & 100 & $76(76.0)$ & $1.13(1.00-1.27)$ & 0.08 \\
\hline $\begin{array}{l}\text { Лечение после } \\
\text { неэффективного лечения }\end{array}$ & 28 & $22(78.6)$ & $1.17(0.95-1.42)$ & 0.22 \\
\hline Лечение после ПДН & 32 & $25(78.1)$ & $1.16(0.96-1.40)$ & 0.20 \\
\hline \multicolumn{5}{|l|}{$\begin{array}{l}\text { Спектр лекарственной } \\
\text { устойчивости }\end{array}$} \\
\hline Чувствительный & 602 & $355(59.0)$ & 1.0 & \\
\hline INH-монорезистентность & 15 & $11(73.3)$ & $1.24(0.91-1.70)$ & 0.30 \\
\hline RMP-монорезистентность & 7 & $4(57.1)$ & $0.97(0.51-1.85)$ & 1.00 \\
\hline Полирезистентность* & 47 & $38(80.9)$ & $1.37(1.18-1.60)$ & +0.01 \\
\hline МлУ-ТБ & 144 & $122(91.0)$ & $1.54(1.42-1.68)$ & +0.001 \\
\hline МЛУ-ТБ+АG/СР & 54 & $50(92.6)$ & $1.57(1.42-1.74)$ & +0.001 \\
\hline МЛУ-ТБ+FQ & 26 & $24(92.3)$ & $1.57(1.38-1.78)$ & +0.001 \\
\hline шлУ-ТБ & 27 & $26(96.3)$ & $1.63(1.48-1.80)$ & +0.001 \\
\hline \multicolumn{5}{|l|}{$\begin{array}{l}\text { Тестирование на ВИЧ } \\
\text { проводилось }\end{array}$} \\
\hline Положительный & 107 & $90(84.1)$ & $1.23(1.12-1.36)$ & +0.001 \\
\hline Отрицательный & 757 & $517(68.3)$ & 1.0 & \\
\hline
\end{tabular}

* Устойчивость минимум к двум препаратам первого ряда, но не МЛУ-ТБ.

ТБ = туберкулез; ОР = отношение рисков; ДИ = доверительный интервал; ПДН = потеря для дальнейшего наблюдения; $\mathrm{INH}=$ изониазид; RMP = рифампицин; МЛУ-ТБ = ТБ $\mathrm{c}$ множественной лекарственной устойчивостью; $\mathrm{AG} / \mathrm{CP}=$ любой инъекционный аминогликозид второго ряда или капреомицин; $\mathrm{FQ}=$ фторхинолон; ШЛУ-ТБ = ТБ с широкой лекарственной устойчивостью; ВИЧ = вирус иммунодефицита человека.

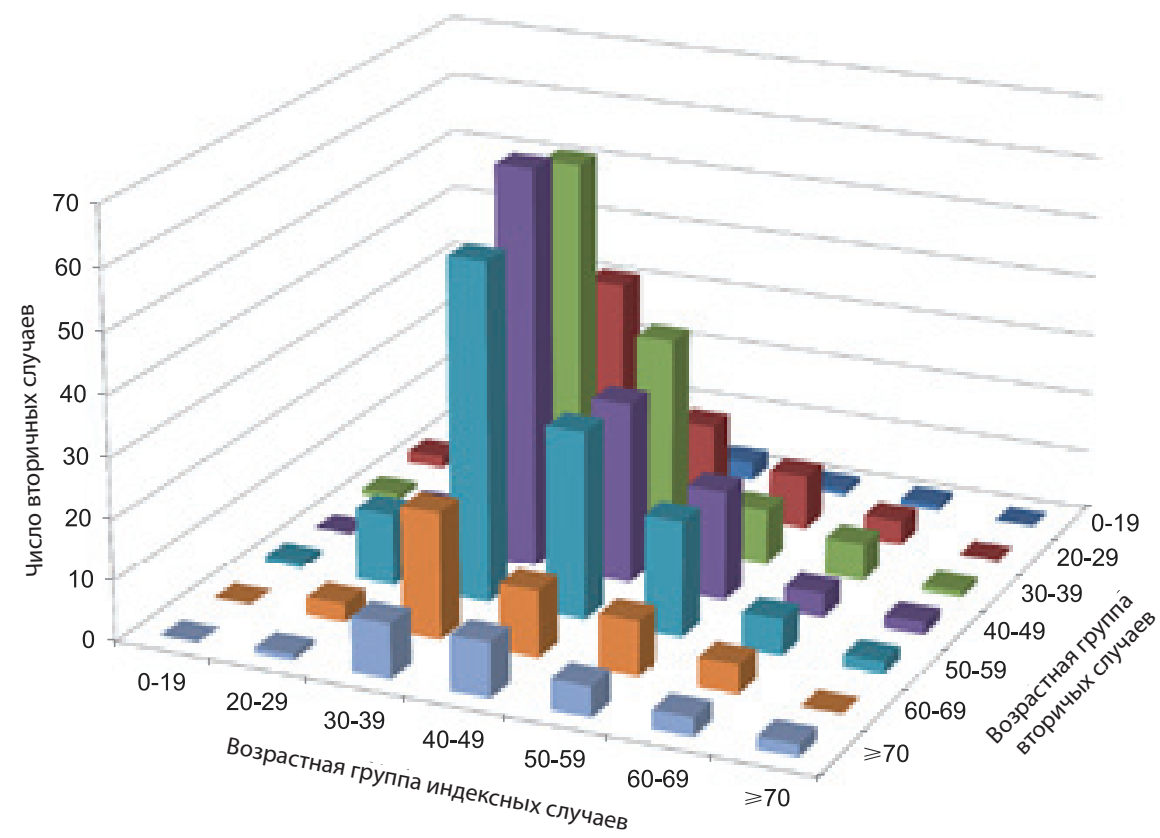

РИсуноК 2 Распределение трансмиссии туберкулеза по возрастным группам индексных случаев и вторичных случаев, Эстония, 2009-2012.

кость этой связи в Эстонии. Другим интересным, но неожиданным выводом стало то, что небольшое число изолятов С
RMP-монорезистентностью относились в основном к семейству LAM (5/7). Стоит отметить, что 4/5 изолятов были распределены по двум 
кластерам, а один имел уникальный VNTR-паттерн. Это указывает и на недавнюю трансмиссию RMP-монорезистентного ТБ и на независимое развитие данного спектра устойчивости. Тем не менее, больные с RMP-монорезистентностью нуждаются в лечении МЛУ-ТБ, а не в препаратах первого ряда, ${ }^{26}$ что указывает на необходимость более пристального мониторинга данного типа лекарственной устойчивости в будущем.

Во-вторых, более 70\% изолятов входили в кластеры, что говорит о высоком уровне недавней трансмиссии ТБ в сообществе. Это существенно выше показателей основанных на анализе случаев 20 -и летней давности (49\%). ${ }^{10}$ Важно то, что были выделены кластеры, позволяющие предположить наличие цепочек трансмиссии, состоящих из больших групп $\geq 10$ человек. Самый большой кластер -178 изолятов был представлен штаммом семейства Beijing, который по последним отчетам является основным источником М/ШЛУ-ТБ в странах Европейского Союза. 27 В этом самом крупном кластере распространенность М/ШЛУ-ТБ превысила 90\%. Это говорит об активном, широком распространении М/ШЛУ-ТБ клонов изолятов M. tuberculosis семейства Beijing в Эстонии, что вызывает серьезную озабоченность и говорит о необходимости новых мер профилактики распространения инфекции в исследуемых популяциях. Однако преобладание данного кластера Beijing 100-32 и вообще изолятов семейства Beijing означает, что мы должны с осторожностью трактовать результаты кластеризации с точки зрения возможности недавней трансмиссии. Несмотря на высокую дискриминирующую способность, 24-х локусное VNTR-типирование не обладает достаточным разрешением для точного различения близко связанных клонов, составляющих популяцию штамма Beijing, по сравнению с IS6110-RFLP или с использованием дополнительных гипервариабельных VNTR локусов.8,28 Таким образом наша оценка недавней трансмиссии может быть слегка завышенной.

В-третьих, мы установили, что определенные социально-демографические и клинические факторы имели сильную связь с формированием кластеров, что указывает на то, что выделенные кластеры довольно точно отражают недавнюю трансмиссию. К таким факторам относилось отсутствие постоянного места жительства, злоупотребление алкоголем, пребывание в прошлом в местах лишения свободы и наличие полирезистентного ТБ, МЛУ- или ШЛУ-ТБ или ВИЧ-инфекции. Тогда как связь между формированием кластеров и пребыванием в местах лишения свободы, алкогольной зависимостью, М/ШЛУ-ТБ и ВИЧ инфекцией хорошо известна, 29,30 связь с другими факторами еще не изучена. Однако, кажется логичным, что лица, не имеющие постоянного места жительства, подвержены большему риску развития ТБ, 31 могут формировать резервуар инфекции и способствовать ее дальнейшей трансмиссии. Нам не известно о предыдущих отчетах о сильной связи между полирезистентным ТБ и недавней трансмиссией. Большинство полирезистентных изолятов входили в кластеры и также принадлежали семейству Beijing. Это важно, т.к. полирезистентные штаммы Beijing были ассоциированы с риском нарастания лекарственной устойчивости вплоть до развития МЛУ-ТБ. 32 Поэтому пути трансмиссии полирезистентных шиаммов также необходимо тщательно контролировать.

В-четвертых, мы обнаружили, что определенные факторы были связаны с меньшим риском недавней трансмиссии. У больных внелегочным ТБ риск недавней трансмиссии был на 65\% меньше, по сравнению с больными ТБ легких, что отражает преобладающую неинфекционную природу внелегочного ТБ. У больных, рожденных в Украине, риск формирования кластеров был существенно ниже, возможно изза того, что еще на родине они приобретают латентную ТБ инфекцию, которая активируется после переезда в Эстонию. Пожилой возраст был также фактором, связанным с существенно меньшим риском недавней трансмиссии, что может быть отражением усиливающейся изоляции пожилых людей в современном обществе.
Сильной стороной исследования было большое число включенных в исследование больных, общенациональный охват исследования и интеграция молекулярно-эпидемиологических данных в анализ факторов риска программы борьбы с ТБ. Проведение исследования и отчетность по нему соответствовали международным рекомендациям по отчетности о наблюдательных исследованиях. ${ }^{33,34}$

Имело место два ограничения. Во-первых, не проводилось подробного эпидемиологического изучения контактов; поэтому механизм трансмиссии от человека к человеку внутри кластера остается неясным. Во-вторых, для кластерного анализа и определения принадлежности к генетическому семейству мы использовали только данные VNTR-типирования. Сполиготипирование, которое имеется, но в настоящее время не используется в Эстонии, и дополнительное использование VNTR-типирования гипервариабельных локусов изолятов Beijing позволило бы с большей точностью определить принадлежность к семейству и обеспечило бы точную дискриминацию случаев внутри кластера. ${ }^{28,35}$ Однако, как уже говорилось выше, проведенный нами анализ факторов риска формирования кластеров позволяет с большой долей уверенности судить о эпидемиологической значимости выделенных кластеров.

Наиболее важным значением данного исследования является то, что оно показало значимость молекулярной эпидемиологии для понимания механизмов распространения эпидемии ТБ в Эстонии и, в частности, трансмиссии представляющих наибольшую угрозу форм МЛУ- и ШЛУ-ТБ. Важно продолжать поддержку данной области, осуществлять инвестиции в технологии молекулярной эпидемиологии и далее укреплять связь с НПТ.

В заключение отметим, мы показали, что в Эстонии имеет место высокая и, пожалуй, набирающая темпы трансмиссия ТБ особенно в определенных группах высокого риска, что обусловлено М/ШЛУ-ТБ и принадлежностью выделяемых изолятов к семейству Beijing.

\section{Список литературы}

1 World Health Organization. The global plan to stop TB 2011-2015: transforming the fight towards elimination of tuberculosis. Geneva, Switzerland: WHO, 2011.

2 European Centre for Disease Prevention and Control. Tuberculosis surveillance and monitoring in Europe 2014. Stockholm, Sweden: ECDC, 2014.

3 Kliiman K, Altraja A. Predictors of extensively drug-resistant pulmonary tuberculosis. Ann Intern Med 2009; 150: 766-775.

4 van der Zanden A G, Rahim Z, Fedder G, et al. Multiple Mycobacterium tuberculosis infections in an HIV-infected patient. Southeast Asian J Trop Med Public Health 2007; 38: 704-705.

5 van Embden J D, Cave M D, Crawford J T, et al. Strain identification of Mycobacterium tuberculosis by DNA fingerprinting: recommendations for a standardized methodology. J Clin Microbiol 1993; 31: 406-409.

6 Supply P, Allix C, Lesjean S, et al. Proposal for standardization of optimized mycobacterial interspersed repetitive unit-variable-number tandem repeat typing of Mycobacterium tuberculosis. J Clin Microbiol 2006; 44: 4498-4510.

7 Allix-Beguec C, Fauville-Dufaux M, Supply P. Three-year population-based evaluation of standardized mycobacterial interspersed repetitive-unit-variable-number tandem-repeat typing of Mycobacterium tuberculosis. J Clin Microbiol 2008; 46: 1398 1406.

8 de Beer J L, van Ingen J, de Vries G, et al. Comparative study of IS6110 restriction fragment length polymorphism and variable-number tandem-repeat typing of Mycobacterium tuberculosis isolates in the Netherlands, based on a 5-year nationwide survey. $J$ Clin Microbiol 2013; 51: 1193-1198.

9 de Beer J L, Kodmon C, van Ingen J, Supply P, van Soolingen D. Second worldwide proficiency study on variable number of tandem repeats typing of Mycobacterium tuberculosis complex. Int J Tuberc Lung Dis 2014; 18: 594-600.

10 Kruuner A, Hoffner S E, Sillastu H, et al. Spread of drug-resistant pulmonary tuberculosis in Estonia. J Clin Microbiol 2001; 39: 3339-3345.

11 Devaux I, Kremer K, Heersma H, Van Soolingen D. Clusters of multidrug-resistant Mycobacterium tuberculosis cases, Europe. Emerg Infect Dis 2009; 15: 1052-1060.

12 Cirillo D. TB PAN-NET: Pan-European network for study and clinical management of drug resistant tuberculosis. Milan, Italy: TB PAN-NET, 2009-2013.

13 Tiit Eesti Matemaatika Selts. The census of people and housing. Overview of the population in Estonian counties. Tallinn, Estonia: Data Protection Agency, 2013.

14 World Health Organization. Multidrug and extensively drug-resistant TB (M/XDR-TB): 2010 global report on surveillance and response. WHO/HTM/TB/2010.3. Geneva, Switzerland: WHO, 2010. 
15 World Health Organization. Treatment of tuberculosis: guidelines. 4th ed. WHO/HTM/ TB/2009.420. Geneva, Switzerland: WHO, 2009.

16 Rüsch-Gerdes S, Pfyffer G E, Casal M, Chadwick M, Siddiqi S. Multicenter laboratory validation of the BACTEC MGIT 960 technique for testing susceptibilities of Mycobacterium tuberculosis to classical second-line drugs and newer antimicrobials. J Clin $\mathrm{Mi}-$ crobiol 2006; 44: 688-692.

17 World Health Organization. Policy guidance on drug-susceptibility testing (DST) of second-line antituberculosis drugs. WHO/HTM/TB/2008.392. Geneva, Switzerland: WHO, 2008.

18 Cowan L S, Hooks D P, Christianson S, et al. Evaluation of mycobacterial interspersed repetitive-unit-variable-number tandem-repeat genotyping as performed in laboratories in Canada, France, and the United States. J Clin Microbiol 2012; 50: 1830-1831; author reply 1832 .

19 Weniger T, Krawczyk J, Supply P, Niemann S, Harmsen D. MIRU-VNTRplus: a web tool for polyphasic genotyping of Mycobacterium tuberculosis complex bacteria. Nucleic Acids Res 2010; 38: W326-331.

20 Sokal R R, Michener C D. A statistical method for evaluating systematic relationships. Univ Kansas Sci Bull 1958; 38: 1409-1438.

21 Allix-Beguec C, Niemann S, Weniger T, Supply P, Harmsen D. Automated web based identification of Mycobacterium tuberculosis genotypes: Evaluation and user-strategy of the MIRU-VNTRplus database. J Clin Microbiol 2008; 298: 93.

22 Saitou N, Nei M. The neighbor-joining method - a new method for reconstructing phylogenetic trees. Mol Biol Evol 1987; 4: 406-425

23 Allix-Beguec C, Harmsen D, Weniger T, Supply P, Niemann S. Evaluation and strategy for use of MIRU-VNTRplus, a multifunctional database for online analysis of genotyping data and phylogenetic identification of Mycobacterium tuberculosis complex isolates. J Clin Microbiol 2008; 46: 2692-2699.

24 Mokrousov I, Jiao W W, Sun G Z, et al. Evolution of drug resistance in different sublineages of Mycobacterium tuberculosis Beijing genotype. Antimicrob Agents Chemother 2006; 50: 2820-2823.

25 Glynn J R, Kremer K, Borgdorff M W, Rodriguez M P, van Soolingen D, European concerted action N. Beijing/W genotype Mycobacterium tuberculosis and drug resistance. Emerg Infect Dis 2006; 12: 736-743.
26 World Health Organization. Multidrug-resistant TB (MDR-TB): 2013 update. Geneva Switzerland: WHO, 2013. http://www.who.int/tb/challenges/mdr/mdr_tb_factsheet. pdf?ua=1 Accessed August 2014.

27 De Beer J L, Kodmon C, van der Werf M J, van Ingen J, van Soolingen D, the ECDC MDR-TB molecular surveillance project participants. Molecular surveillance of multi -and extensively drug-resistant tuberculosis transmission in the European Union from 2003 to 2011. Euro Surveill 2014; 19: pii: 20742.

28 Allix-Beguec C, Wahl C, Hanekom M, et al. Proposal of a consensus set of hypervariable mycobacterial interspersed repetitive-unit-variable-number tandem-repeat loci for subtyping of Mycobacterium tuberculosis Beijing isolates. J Clin Microbiol 2014; 52: 164-172.

29 Alland D, Kalkut G E, Moss A R, et al. Transmission of tuberculosis in New York City: an analysis by DNA-fingerprinting and conventional epidemiologic methods. $\mathrm{N}$ Engl J Med 1994; 330: 1710-1716.

30 Mokrousov I, Valcheva V, Sovhozova N, Aldashev A, Rastogi N, Isakova J. Penitentiary population of Mycobacterium tuberculosis in Kyrgyzstan: Exceptionally high prevalence of the Beijing genotype and its Russia-specific subtype. Infect Genet Evol 2009; 9: $1400-1405$.

31 Lönnroth K, Jaramillo E, Williams B G, Dye C, Raviglione M. Drivers of tuberculosis epidemics: the role of risk factors and social determinants. Soc Sci Med 2009; 68: 22402246.

32 Cox H S, Niemann S, Ismailov G, et al. Risk of acquired drug resistance during shortcourse directly observed treatment of tuberculosis in an area with high levels of drug resistance. Clin Infect Dis 2007; 44: 1421-1427.

33 von Elm E, Altman D G, Egger M, et al. The Strengthening the Reporting of Observational Studies in Epidemiology (STROBE) statement: guidelines for reporting observational studies. Ann Intern Med 2007; 370: 1453-1457.

34 Edginton $\mathrm{M}$, Enarson $\mathrm{D}$, Zachariah $\mathrm{R}$. Why ethics is indispensible for good-quality operational research. Public Health Action 2012; 2: 21-22.

35 Oelemann M C, Diel R, Vatin V, et al. Assessment of an optimized mycobacterial interspersed repetitive-unit-variable-number tandem-repeat typing system combined with spoligotyping for population-based molecular epidemiology studies of tuberculosis. J Clin Microbiol 2007; 45: 691-697.
Public Health Action (PHA) - голос операционных исследований. Издаваемый Союзом по борьбе с ТБ и болезнями легких (www.theunion.org) журнал является платформой для реализации его миссии - "Решения проблем здравоохранения для бедных". РНА публикует результаты высококачественных научных исследований, предоставляющих новые данные для решения вопросов равенства, улучшения доступности и эффективности систем здравоохранения и медицинской помощи.
e-ISSN 2220-8372

Главный редактор: Donald A Enarson, MD, Canada

Контактные данные: pha@theunion.org

Веб-сайт PHA: http://www.theunion.org/index.php/en/journals/pha

Статьи направлять по адресу: http://mc.manuscriptcentral.com/pha 